\title{
30 Realising employer liability for informal workers
}

\author{
Lessons from India
}

\author{
Kamala Sankaran
}

The lack of social protection has often been used as a criterion to identify those in informal employment. ${ }^{1}$ While poor working conditions and other deficits in decent working conditions exist, the lack of social protection to deal with various risks and contingencies is often singled out as a critical aspect of those in informal employment. Consequently, policy-makers who wish to facilitate a transition from informality to formality have, among various options available for this transition, also focused on providing some level of social protection to vulnerable sections of those informally employed. For instance, in India, the Unorganised Workers Social Security Act, 2008, provides some form of limited social security to those persons who are employed or self-employed and who do not have access to the broader and deeper coverage of social protection available to those in more formal employment relationships. This chapter examines the method of financing minimum forms of social protection through the system of "cess-financing" (levied as a duty on total turnover or sales) used in India and its relevance today to provide social protection for all.

Achieving uniformity in the levels of social protection may be a sought-after goal but financial and functional considerations often result in varying levels of social protection available, particularly, for those in informal employment (who often receive no or lower levels of social protection). Traditionally, financing of many social security schemes has been contributory (with both employers and employees contributing differing amounts) or exclusively employer-liability schemes where the entire cost is borne by the employer. ${ }^{2}$ India has experimented with a number of social welfare (benefits) schemes that offer a modicum of social protection that are not financed through such employer-liability or contributory schemes but are financed through publicly levied "cesses" upon the industry concerned to finance the payment of such welfare benefits. For example, for several years (until as recently as 2017) a cess used to be levied on the production of salt to provide for certain benefits in the form of minimum working conditions for workers in salt mines. These benefits were the provision of drinking water (an essential requirement considering that salt production in the informal sector requires workers to work several hours a day in the searing sun with their feet immersed in saline water), gloves, safety equipment like goggles and boots, in addition to crucial health camps and crèches. These "benefits" have been 
funded by levying a cess on salt manufacture and with the government agency/ commission administering the necessary welfare benefits. In other industries such as the construction industry, where the cess is collected based upon the value of construction, the welfare benefits include, for example, pension, maternity assistance, medical assistance and housing assistance. The benefits provided to registered workers in the construction industry are more akin to the traditional forms of social security while the benefits provided in relatively poorer industries, where the cesses collected are lower, are more akin to forms of social assistance and improvement of working conditions and do not cover the risks and contingencies usually associated with social security.

The ability of the state to levy such a cess requires legislation to be imposed since the cess is nothing other than a tax, not a generalised tax but a specific tax imposed on a specific industry and for a specific purpose. Typically, a cessrelated law would grant the power to the state to impose such a cess and it would also indicate the benefits that are to be provided from the collections received. ${ }^{3}$ In a very loose sense, such legislation could be seen as creating a right held by the workers to claim such benefits; however, the various laws that authorise the collection of such cesses do not create corresponding rights on the part of the workers to ensure that the cesses are collected in accordance with the law nor do they provide for an adequate voice to workers in the allocation of these funds for financing the promised benefits. Where the worker organisations raise the issue of inadequate coverage of cess collection, such claims are only available against the state and not the employer. ${ }^{4}$

The benefits are contingent upon the timely collection of cesses by the state agencies based on a correct assessment of production or turnover. Although they are administered by the labour departments, the assessment of potential cesses requires necessary economic inputs and requisite revenue intelligence to ensure the maximisation of cess collection. Evasion and non-coverage of economic units and employers are a chronic problem plaguing the labour departments which are dependent upon the cess collections to provide the benefits which are promised under these laws. ${ }^{5}$ For instance, many of the unregistered beedi (handrolled cigarettes) units employ women at home and it has been noted that such home-based workers are less likely to be covered by welfare benefits as compared to factory workers. ${ }^{6}$ The advantage that a cess-related system of social protection has is that it taxes the final product/turnover and that all subcontracting chains in the production chain also are made liable, albeit indirectly, and have to contribute to the social protection provided to all workers. Further, since benefits are provided by the labour departments and not individual employers or units, the need to identify sub-contractors in order to make them contribute to such benefits does not arise.

As noted above, the cess-based system of funding social protection derives its resources from taxing the industry as a whole. The justification for such a cess has been upheld on the ground that the beneficiaries are those working in the system and the incidence of the cess falls upon the employers who are engaged in producing the output or product, and can therefore justifiably be required to 


\section{Kamala Sankaran}

bear the cost of the benefits. The cess is usually fixed as a proportion of the value of the product/turnover irrespective of the numbers of employees who produce that output. An establishment or unit producing, for example, salt, in a unit where productivity is high and where the workforce is small could end up paying a higher cess calculated as a percentage on output even though such a unit, if it had been covered by a traditional social protection scheme and where the liability is determined on an employee basis, could have contributed a relatively lower amount, since the contribution of the employer would have been determined on the basis of the number of employees and their wages.

The question whether those not directly involved in the production of goods and services can also be asked to contribute through a cess to the welfare and social protection benefits in a sector/industry is more problematic. The state of Kerala in India had sought to create a welfare fund for fish workers, including self-employed fish workers, by levying a cess on fish traders and collecting a percentage of their turnover/sales for the proposed welfare fund. This law was challenged by the fish traders as unconstitutional some years ago on the grounds that these traders (who occasionally provided credit to self-employed fish workers) could not be compelled to contribute to the welfare fund as there is no employer-employee relationship between the fish trader and the fish worker who is the beneficiary of such a welfare fund. On the challenge, the Supreme Court observed:

State cannot ... place the burden of an impost by way of contribution for giving effect to the Act and the Scheme made thereunder for the social security and social welfare of a section of society upon a person who is not a member of such section of society nor an employer of a person who is a member of such section of society. The burden of the impost may be placed only when there exists the relationship of employer and employee between the contributor and the beneficiary of the provision of the Act and the Scheme made thereunder. ${ }^{7}$

Thus, according to this reasoning, the justification for collection of a cess is based primarily on the employer and where the unit or industry employs workers who produce the output. However, this rigid restriction of the power to collect such a cess applies only to instances where an employer-employee relationship exists that has been loosened in recent times. A recent case before the Supreme Court has upheld a cess levied on all litigants in the state of Kerala to contribute to a welfare fund meant for the benefit of advocates appearing in state courts. The Kerala Court Fees and Suits Valuation Act, 1959 permits the collection of an additional fee (based on the value of the suit, i.e., the value of the relief sought) from all litigants approaching the court for relief to contribute to the Advocate Welfare Fund to provide some social protection to the advocates at the time of retirement/cessation of practice/death. The additional fee is payable irrespective of whether or not the litigant engages a lawyer/advocate for his/her court case. The additional levy to contribute to the welfare fund for advocates 
was challenged in the Supreme Court. The court upheld this levy and stated: "[I]t becomes apparent that providing social security to the legal profession becomes an essential part of any legal system which has to be effective, efficient and robust to enable it to provide necessary service to the consumers of justice." The court can be seen to be endorsing a system of cess/tax on stakeholders/consumers of an industry, in order to pay for the welfare of those engaged or working in such an industry. Yet, the constitutional scheme requires legislation to be put in place prior to the levy of such a cess/tax. Such cess-based welfare schemes are applicable only in certain industries in India, such as building and construction, beedi (hand-rolled cigarettes) and certain non-ferrous mines. The cess-system of financing welfare contributions has been used in India in a variety of sectors, particularly those where informal employment is predominant. Recently, as part of the rationalisation of the tax systems across India, the major cess-based systems were abolished with the introduction of a Goods and Service Tax (GST) from July 2017. The result has been a drying-up of resources for the specific industries which used cesses to finance welfare funds. There has been mounting opposition to the abolition of cess-financed welfare and social protection benefits. There is a fear that the specific welfare measure developed over the years for specific industries and the measures provided at local levels, such as the benefits provided for beedi workers, salt workers or cine-workers, would not be reflected in the general social security or welfare measures within a 'one-sizefits-all' approach to the delivery of such benefits. Further, delivery of these benefits was earlier handled in certain industries through tripartite welfare boards. ${ }^{9}$ The proposed Code on Social Security has tripartite bodies at the central and state levels to monitor the delivery of social security. Yet the number of government and legislative representatives in these bodies is significantly larger, causing further anxiety over the erosion of the tripartite nature of such boards/ councils. The approach in recent times has been to introduce greater uniformity and consolidation of benefits across industries that has caused disquiet among trade unions in sectors which had fought for and achieved industry-specific welfare funds and delivery of benefits. On the other hand, the costs of collecting the cess from each industry and the burden placed on the labour departments have been enormous, prompting the justification that such labour-specific cesses also be viewed as a form of tax on goods (thereby justifying the amalgamation of all cesses into the GST) and as introducing a long-overdue uniformity and efficiency in the selection and delivery of welfare benefits provided across industries.

Future research could examine the capacity of a universal tax (such as a GST) that is administered in a centralised manner to finance customised welfare benefits for marginalised and difficult-to-identify groups of workers, such as homebased workers and whether the efficiency of universal social security benefits outweighs the customised and relatively easier-to access benefits of such cessfinanced welfare benefits. However, given the low levels of coverage of social protection in India and the lack of effective social protection systems, the abolition of such cesses and the failure to put in place alternate funding for financing these modest welfare benefits remain a cause for concern. 


\section{Acknowledgements}

This chapter draws on previously published work as well as research done as part of the WIEGO Law Projects.

\section{Notes}

1 Section 2(m) of the Unorganised Workers Social Security Act, 2008.

2 In India, for instance, the Maternity Benefit Act, 1961 is an exclusively employer liability funded scheme, while the more widespread Employees' Provident Fund Scheme or the Employees' State Insurance Scheme, which cover important social security benefits for workers in large units and their families, are contributory schemes.

3 See the Building and Other Construction Workers Welfare Cess Act, 1996, the Beedi Workers Welfare Cess Act, 1976, and the Iron Ore, Manganese Ore and Chrome Ore Mines Labour Welfare Cess Act, 1976.

4 The building and construction workers union has successfully used public interest litigation to compel various states in India to form rules regarding the collection and use of cess funds collected for their industry. There is a need for continuous monitoring and the use of the large amount of cess funds collected for the construction industry has been the principal preoccupation of many of the trade unions in this sector. See, for instance, a key ongoing litigation National Campaign Committee for Central Legislation on Construction Labour v. Union of India, Writ Petition (Civil) No. 318 of 2006 in which dozens of orders have already been assessed by the Supreme Court of India, and where related petitions have also been filed by the worker organisations for implementation of certain orders.

5 Moving production to smaller unregistered manufacturing units is one way to avoid paying the necessary cess and duties. See ILO (n.d.).

6 See Joh (n.d.).

7 Koluthara Exports Ltd. v. State of Kerala \& Ors (2002(2) SCC 459), Hindustan Times v. State of Uttar Pradesh decided 1 November 2002.

8 Cardamom Marketing Corporation and Anr v. State of Kerala and Ors, (2017) 5 Supreme Court Cases 255.

9 See Chapter 32 by Rina Agarwala in this volume for the role played by the tripartite boards in the delivery of benefits to informal workers. 